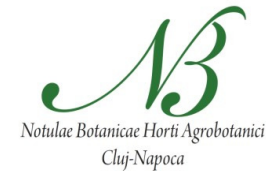

\title{
The Critical Period for Weed Control (CPWC) in Potato (Solanum tuberosum L.)
}

\author{
Dogan $\mathrm{ISIK}^{1 *}$, Adem AKCA², Emine KAYA ALTOP², \\ Nihat TURSUN ${ }^{4}$, Husrev MENNAN ${ }^{3}$

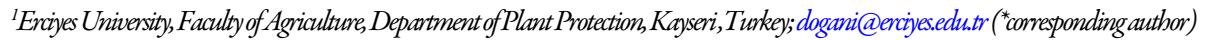 \\ ${ }^{2}$ KWSTukkTarim,Kayseri, Turkey; adem.akca@kws.com \\ 3OndokuzMayusUniversity,Faculty of Agriculture,DepartmentofPlantProtectiom,Samsun,Turkey; kayae@omu.edutr; hmennan@omuedu.tr \\ 4InonuUniversity, Faculty of Agriculture,Department of PlantProtection,Malatya,Turkey;nihat.turun@inonu.edu.tr
}

\begin{abstract}
Accurate assessment of crop-weed control period is an essential part for planning an effective weed management for cropping systems. Field experiments were conducted during the seasonal growing periods of potato in 2012 and 2013 in Kayseri, Turkey to assess critical period for weed control (CPWC) in potato. A four parameter log-logistic model was used to assist in monitoring and analysing two sets of related, relative crop yield. Data was obtained during the periods of increased weed interference and as a comparison, during weed-free periods. In both years, the relative yield of potato decreased with a longer period of weed-interference whereas increased with increasing length of weed free period. In 2012, the CPWC ranged from 112 to 1014 GDD (Growing Degree Days) which corresponded to 8 to 66 days after crop emergence (DAE) and between 135-958 GDD (10 to 63 DAE) in the following year based on a 5\% acceptable yield loss. Weed-free conditions needed to be established as early as the first week after crop emergence and maintained as late as ten weeks after crop emergence to avoid more than 5\% yield loss in the potato. The results suggest that CPWC could well assist potato producers to significantly reduce the expense of their weed management programs as well as improving its efficacy.
\end{abstract}

Keywords: competition, non-linear regression, potato crop, weed interference, yield

\section{Introduction}

Potato (Solanum tuberosum L.) is grown over a vast global area spanning from latitudes $65^{\prime}$ in the Northern Hemisphere to 50 ' in the Southern Hemisphere and it can be grown up to 4000 meters above sea level (Uremis et al., 2009). Globally, it is the fourth largest consumed plant after corn, rice and wheat. Historically and even today potatoes have played an important role in the fight against malnutrition and starvation (Ahmadvand et al., 2009). Therefore its production is considered essential internationally. Potato tuber contains about 15 to $25 \%$ dry matter and is nutritious particularly in carbohydrates (starches), protein, vitamins (C, B1, B3, B6, K, folate, pantothenic acid) and minerals $(\mathrm{K}, \mathrm{Mn}, \mathrm{Mg}, \mathrm{Fe}, \mathrm{Cu}, \mathrm{P})$ (Gunel et al., 2010). It is also put to many other uses and it is still internationally one of the World's leading nutritional food sources (Uremis et al., 2009). Potato production in Turkey mainly takes place in cool but frost-free temperatures of the highlands and in warmer locations in the lowlands during spring and autumn (Haverkort, 1981). Turkey is one of the highest potatoes producing countries in the Mediterranean region and 3,948 million tons were produced during 2013 from an area of 1.3 million ha (TUIK, 2015).
In common with other crops, weed control in potato crops is a vital part of successful crop production (Solan et al., 2011). The volume of potato tuber production can be significantly decreased by weeds as they compete for nutrients, water and light. Volume is also reduced by diseases and insects inherently carried by weeds if they are not controlled at the correct and critical time (Boydston et al., 2008). Thus, without such control, if one assesses the seasonal growth period in any given annual period, potato yield can fall by as much as $16 \%$ to $76 \%$ (Tripathi et al., 1989). There are varying standards of modern weed management programs depending on the location of the planting region and the type of potato. In Turkey, standard management design procedures incorporate herbicides and cultivation is implemented strategically to manage weeds. Essentially this is done routinely at the beginning of the growing season as young; potato seedlings are highly susceptible to weed competition at this critical time. In fact, even before this, at the pre-planting stage or before plant emergence, herbicides sprays are habitually applied for weed control in potato-growing locations. In contrast, after crop emergence, machine or hand hoeing methods are regularly used for controlling the weeds by potato farmers (Ahmadvand et al., 2009; Felix and Boydston, 2010; Gitsopoulos et al., 2014). 
356

The critical period for weed control (CPWC) criteria provides essential guidance on the relevant time periods in the plantation growth stages during which crops ideally should be kept weed-free to stop yield or quality reductions caused by weed interference (Evans et al., 2003; Zimdahl, 2004). It defines two separate types of weed interference scenarios:

(1) the critical weed interference period or the longest possible period from the time that crops are planted that the crops are able to live together side by side with weeds without unreasonable yield loss occurring, and

(2) the critical weed-free period or the smallest possible period for the crop to be kept weed-free before yield loss effected by weed growth is no longer a problem (Hall et al., 1992; Evans et al., 2003). Thus, the CPWC identifies the most beneficial time periods for the best integrated weed management (IWM) program (Swanton and Weise, 1991).

Critical periods of weed-crop competition for potatoes have been monitored and statistically analysed in only relatively few environments and only for a limited variety of weed types (Baziramakenga and Leroux, 1998; Ciuberkis et al., 2007; Costa et al., 2008; Ahmadvand et al., 2009). On average, the critical period for weed removal in potatoes has been assessed as 4 to 6 weeks from planting. However, Costa et al. (2008) established data demonstrating that in Brazil, the critical period for weed interference was only one day, i.e. 20 to 21 days after tuber planting. Again, by comparison, in the UK, one weeding between 2 to 8 weeks after crop planting was sufficient to stop any significant yield losses. Weeds emergence after these periods (8 WAP) significantly reduced by crop canopy as long as there is $100 \%$ coverage. However, with lower canopy cover, removal of weeds at 2 weeks after planting had no effects because weed growth after this period continued to compete with the crop (Turner et al., 1999). In Canada, allowing plots to be weed-free for 3 weeks was not enough to curtail some reduction in yield. Competition from couch grass (Elytrigia repens (L.) Nevski) occurred virulently after crop emergence and 15 days after crop emergence when numbers of weed seedlings were low (Baziramakenga and Leroux, 1994). Therefore, the principle focus of this research was to determine the CPWC for potato grown in the Central Anatolian Region of Turkey, an area where there is little or no knowledge of CPWC on potato.

\section{Materials and Methods}

\section{Site description}

Field experiments were carried out in 2012 and 2013 on arable farm land at Yeşilhisar Kayseri, in the Central Anatolian region of Turkey. The soil texture of the experimental area was sandy loam soil which was made up of $86 \%$ sand, $4.6 \%$ silt, and $8.94 \%$ clay $\mathrm{pH} 8.5,0.233 \mathrm{mS} \mathrm{cm}^{-1} \mathrm{EC}, 1.93 \%$ lime and $0.4 \%$ organic matter

\section{Experimental design}

The experimental analysis was undertaken in accordance with the local practice in potato production. Initial tillage consisted of autumn and spring chisel plowing and subsequent disking with a harrow. In general, pre-emergence and postemergence herbicides are utilized in the area for weed control of potato. In this study, however, weeding was done by hand hoeing. 'Marabel' potato cultivar was used. The plots were fertilized in two stages. Firstly, basal application of $700 \mathrm{~kg} \mathrm{ha}^{-1}$ of complex fertilizer (15-15-15) and $800 \mathrm{~kg} \mathrm{ha}^{-1}$ of ammonium sulphate (AS) (21-0-0-24 S) were spread onto the plots at the time of sowing. Remaining fertilizers in the season (beginning of stem elongation) were top dressed at a rate of $300 \mathrm{~kg}^{\mathrm{N}}$ Urea ha ${ }^{-1}$ and additional $150 \mathrm{~kg} \mathrm{AS} \mathrm{ha}{ }^{-1}$ was applied three times (total of $\left.450 \mathrm{~kg} \mathrm{ha}^{-1}\right)$ with irrigation water $\left(3 \times 150 \mathrm{~kg}=450 \mathrm{~kg} \mathrm{ha}^{-1}\right)$. The crop was irrigated following sowing and eight times during the season. Amount of irrigation was adjusted to meet crop water needs based on precipitation and air temperature.

The experimental design was a randomized complete block with four replications. Two methods of weed interference treatments were used and these were initiated at crop emergence. To assess the start of the CPWC, weeds were grown along with the crop and compete at 2 weeks interval with potato 0 to 12 week after emergence (WAE). To establish the end of a critical period, plots were completely weeded at biweekly intervals for 0 to $12 \mathrm{WAE}$ with occasional hand hoeing. Untreated weedy control and weed-free control treatments were introduced into both parts of the experiment.

Plots were made with the dimension of $2.8 \mathrm{~m}$ wide, $5 \mathrm{~m}$ long and planted into four rows. Tubers were sown at a spacing of 70 $\mathrm{cm} \times 28 \mathrm{~cm}$. All statistical results were recorded from the inner two rows of every plot.

\section{Weed and crop measurement}

Field experiments were carried out in two different locations over two successive yearly periods. Weed grown naturally in the plots were used and weed population density was determined from an arbitrarily placed 1 meter by 1 meter quadrat. At maturity, the potato was harvested by hand in the two middle rows of each plot.

Species composition and weed density were assessed by categorizing and counting weeds from one meter squared quadrats in each plot. Weeds were clipped at the soil surface and dried at $70{ }^{\circ} \mathrm{C}$ to determine the above-ground dry matter. In both years, final crop harvests were carried out when the potatoes had reached full maturity. Potato tuber yield determinations from each plot were obtained by hand harvesting $4.5 \mathrm{~m}-2$ areas of the middle two rows.

\section{Meteorological data}

Total monthly rainfall $(\mathrm{mm})$ and average temperatures $\left({ }^{\circ} \mathrm{C}\right)$ throughout the experimental period were recorded from the Yeşilhisar Meteorological Station which is broadcast by the Turkish State Kayseri Meteorological Service and these figures were used throughout as being the average daily temperature and total monthly rainfall (Fig. 1).

\section{Growing degree days (GDDs) calculation}

Air GDDs were taken as an independent variable for regression analysis and were assessed by using the method indicated by Gilmore and Rogers (1958) (Eq. 1). The time of crop emergence (DAE) was used as the yardstick for GDD data recording:

$$
G D D=\sum\left[\frac{T_{\max }+T_{\min }}{2}\right]-T_{b}(1)
$$

Where:

$T_{\max }$ and $T_{\min }$ are the daily highest and lowest temperatures $\left({ }^{\circ} \mathrm{C}\right)$ respectively and $T_{b}$ is the base temperature $\left({ }^{\circ} \mathrm{C}\right) .4{ }^{\circ} \mathrm{C}$ was selected as the base temperature (Nasrullah et al., 1992). 


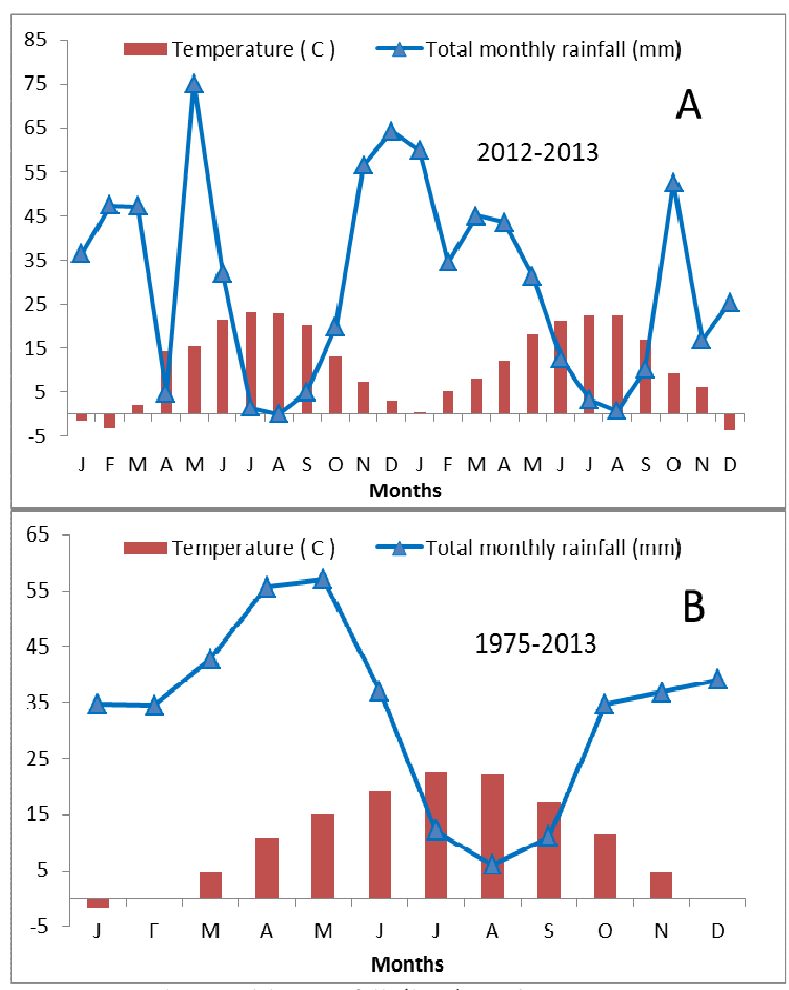

Fig. 1. Total monthly rainfall (line) and average temperature (bar) during 2012 and 2013 (A) and long-term averages from $1975-2013$ (B)

\section{Statistical analysis}

Relative yields and other data were calculated using ANOVA with 'R software' (R Development Core Team, 2006) to evaluate the importance $(\mathrm{p}<0.05)$ of years, treatments, replications and their coexistence. The relative yield of each experimental unit was recorded as a percentage of the corresponding weed-free yield within each replication for each treatment. Due to differences in growing degree days (GDD), which was used as an explanatory variable, in regression analyses, statistical analysis was performed separately for each year. Relative yield (\% of weed-free) data were analysed using the four parameter log-logistic model where the $D$ term was fixed at 100 (Knezevic et al., 2007):

$$
Y=\frac{C+(D-C)}{\{1+\exp [B(\log X-\log E)]\}}
$$

Where:

$Y$ is the response (e.g., relative yield),

$C$ is the lower limit,

$D$ is the upper limit,

$X$ is the GDD calculated after crop emergence,

$E$ is the GDD giving a $50 \%$ response between the upper and lower limit (also known as the inflection point, $I_{50}$ ) and

$B$ is the slope of the line at the inflection point (the rate of change).

The regression analyses were carried out using GDD as a quantitative variable because it is an established biological test measurement of time well suited for assessing the progress of plant growth and development (Gilmore and Rogers, 1958). If one considers the curve fitting procedure, GDD is a more popular variable utilized for fitting regression models compared with a categorical variable (e.g., crop growth stage [CGS]) as GDD provides a constant and more accurate $\mathrm{x}$-axis scale. It therefore follows that it is a better indicator in comparing years and planting date's data from different areas (Knezevic et al., 2002). In addition, GDD can be used together with specific CGS in allowing more expeditious assessments in the field and thus, from a practical point of view, the essential data becomes more readily accessible to producers, consultants and other practitioners (Knezevic et al., 2002).

All statistical analyses were carried out and graphs were drawn up with ' $\mathrm{R}$ software' ( $\mathrm{R}$ Development Core Team, 2006) utilizing the DRC (dose-response curves) statistical add-on package (Knezevic et al., 2007; Knezevic and Datta, 2015). The values of $\mathrm{YR}_{2.5}$ (2.5\% yield reduction), $\mathrm{YR}_{5}$ (5\% yield reduction) and $\mathrm{YR}_{10}$ (10\% yield reduction) were obtained from the curves giving a target range for measuring the effects of increased periods of weed presence and weed-free treatments on crop yield. The $2.5 \%, 5 \%$ and $10 \%$ yield reductions were expressed in GDD indicating the influence of the duration of weed interference. The GDD estimate relating to the $90 \%, 95 \%$ and $97.5 \%$ relative yield was calculated from Eq. (2) for each year and then the same was related to the corresponding DAE. In the study, a maximum yield loss of 5\% was arbitrarily assigned as the value above which yield reduction was determined as being unacceptable (Knezevic et al., 2007).

\section{Results and Discussion}

\section{Weed density and dry matter}

The weed populations were similar in both years (Table 1). The most common weeds in the experimental area were redroot pigweed (Amaranthus retroflexus L.), common lambsquarters (Chenopodium album L.), field bindweed (Convolvulus arvensis L.), puncturevine (Tribulus terrestris L.), common cocklebur (Xanthium strumarium L.), barnyardgrass (Echinochloa crus-galli (L.) Beauv.) and prickly Russian thistle (Salsola ruthenica L.). These seven species of weed made up 87 and 91\% of the total weed mass in 2012 and 2013, respectively. All these weeds are common in other summer grown crops in this location as well (Akca and Isik, 2013). Previous study indicated that some of these weeds (A. retroflexus, C. album, X. strumarium, E. crusgalli) were same in other cultivated crops in Turkey (Bukun,

Table 1. The population density (plants $\mathrm{m}^{-2}$ ) of weed species in the season-long weedy treatment in the experimental area

\begin{tabular}{lcc}
\hline \multirow{2}{*}{ Weed species } & \multicolumn{2}{c}{ Density $\left(\right.$ plants $\mathrm{m}^{-2}$ )/Years } \\
\cline { 2 - 3 } & 2012 & 2013 \\
\hline Amaranthus retroflexus $\mathrm{L}$. & 16 & 24 \\
Chenopodium album L. & 12 & 16 \\
\hline Convolvulus arvensis $\mathrm{L}$. & 4 & 5 \\
Tribulus terrestris $\mathrm{L}$. & 4 & 6 \\
Xanthium strumarium L. & 7 & 9 \\
Echinochloa crus-galli (L.) Beauv. & 6 & 9 \\
Salsola ruthenica L. & 8 & 10 \\
Sinapis arvensis L. & 4 & 2 \\
\hline Sisymbrium altissimum L. & 2 & 1 \\
\hline Acroptilon repens L. DC. & 0.2 & 0.4 \\
Alhagi pseudalhagi L. & - & 0.2 \\
Total & 63.02 & 82.6 \\
\hline
\end{tabular}


358

2004; Isik et al., 2006; Tursun et al., 2012). Such weed species are abundant and important weeds in Turkey. The total weed dry matter went up as the duration of weed interference period increased. The total weed dry matter was higher in 2013 than 2012 (Fig. 2, Table 2) and the weeds acquisition weight increased more in 2013 than in 2012. These figures were established by assessment of the weed density in 2013 (Table 1). These findings were in agreement with Ahmadvand et al. (2009) who reported that as the duration of weed infestation increased weed biomass also increased, but as the duration of weed-free period increased the biomass of the weeds decreased.

\section{Criticalperiod for weed control}

There was an interaction between the year and the treatments in both the years at the beginning and at the end of the CPWC; therefore, all yield data was assessed separately for each year (Fig. 3, Table 3). The relative yield of potato was altered by the duration of weed interference or weed free periods (Fig. 3). Increasing periods of weed interference markedly reduced potato yields in both years. While average potato yields from the seasonlong weed-free plots were $85,000 \mathrm{~kg} \mathrm{ha}^{-1}$ in 2012 and 78,600 kg $\mathrm{ha}^{-1}$ in 2013; from the season-long weed infested plots were $18,425 \mathrm{~kg} \mathrm{ha}^{-1}$ in 2012 and $6,678 \mathrm{~kg} \mathrm{ha}^{-1}$ in 2013. These results were similar to Ahmadvand et al. (2009) who recorded lower potato yields with increasing weed interference.

The CPWC varied in both years (Fig. 3). The length of the CPWC in potato was 70, 58, and 44 days in 2012 and 65, 53, 40 days in 2013 with 2.5, 5 and 10\% acceptable yield loss levels (AYL), respectively. $5 \%$ is as a rule, accepted for most crops in Turkey (Isik et al., 2006). The CPWC in potato was commenced on 112 GDD in 2012 and 135 GDD in 2013, which is equivalent to 8-10 DAE, at 5\% acceptable yield loss (AYL) (Table 4). Based on the 2.5 and 10\% AYL onset of the CPWC were 75-171 GDD in 2012 (6-13 DAE) and 99-186 GDD in 2013 (7-15 DAE). The beginning of the CPWC was at an earlier date in 2012 compared to 2013. The soil and weather conditions in 2012 would have influenced the beginning of the CPWC in a bit earlier in 2012 (6-13 DAE) compared to 7-15 DAE in 2013 (Table 4).

Table 2. Regression parameters by year and practice for the four-parameter logistic model (Eq. 2) characterizing the influence of the duration of weed interference on weeds drymatter $\left(\mathrm{g} \mathrm{m}^{-2}\right)$

\begin{tabular}{ccccc}
\hline \multirow{2}{*}{ Years } & \multicolumn{4}{c}{ Regression parameters, as mean \pm S.E. } \\
\cline { 2 - 5 } & $B$ & $C$ & $D$ & $I_{50}$ \\
\hline 2012 & $-2.8 \pm 0.3$ & $9.0 \pm 52.6$ & $5126.3 \pm 218.8$ & $912.1 \pm 40.42$ \\
2013 & $-3.7 \pm 0.4$ & $1.5 \pm 82.1$ & $5178.5 \pm 188.6$ & $771.9 \pm 26.9$ \\
\hline
\end{tabular}

$B$ : the slope of the line at the inflection point; $C$ : the lower limit; $D$ : the upper limit; $I_{50}$ : the GDD giving a $50 \%$ response between the upper and the lower limit.

Table 3. Parameter estimates by year and practice for the four-parameter logistic model (Eq. 2) characterizing the influence of the duration of weed interference on the relativeyield of potato at Kayseri, Turkey (Fig. 3)

\begin{tabular}{llrccc}
\hline \multirow{2}{*}{ Year } & \multirow{2}{*}{ Treatments } & \multicolumn{4}{c}{ Regression parameters, as mean \pm S.E. } \\
\cline { 3 - 6 } & & \multicolumn{1}{c}{$B$} & \multicolumn{1}{c}{$C$} & \multicolumn{1}{c}{$D$} & \multicolumn{1}{c}{$I_{50}$} \\
\hline 2012 & weedy & $1.8 \pm 0.4$ & $11.7 \pm 7.8$ & $96.5 \pm 3.0$ & $585.9 \pm 66.7$ \\
2012 & weed-free & $-3.9 \pm 1.3$ & $24.9 \pm 3.9$ & $104.4 \pm 7.5$ & $477.2 \pm 30.5$ \\
2013 & weedy & $2.3 \pm 0.3$ & $9.0 \pm 4.1$ & $98.2 \pm 2.3$ & $484.4 \pm 29.7$ \\
2013 & weed-free & $-4.2 \pm 1.9$ & $21.8 \pm 4.3$ & $93.1 \pm 7.4$ & $474.2 \pm 28.4$ \\
\hline
\end{tabular}

$B$ : the slope of the line at the inflection point; $C$ : the lower limit; $D$ : the uppe limit; 150: the GDD giving a 50\% response between the upper and the lower limit.

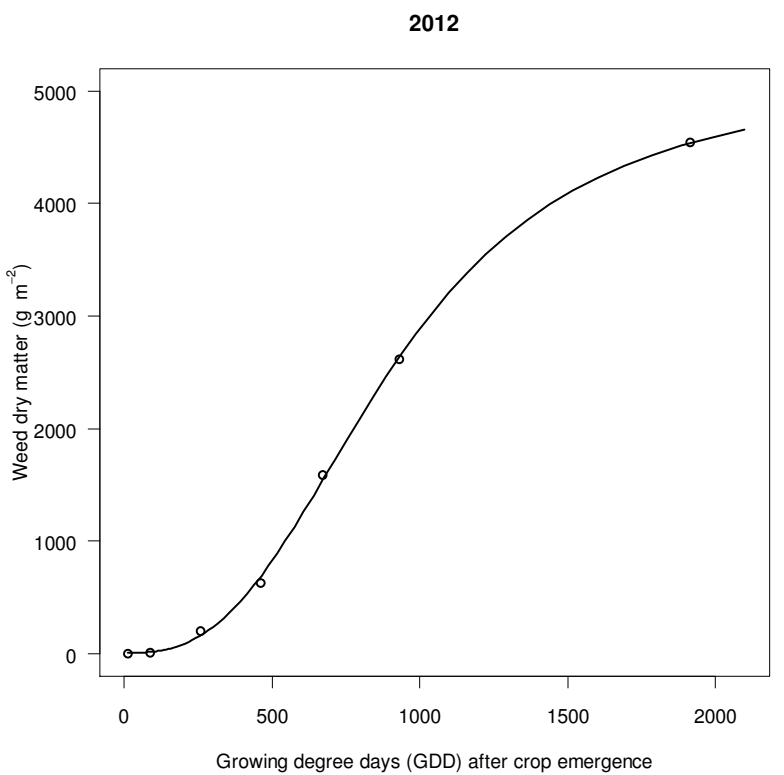

2013

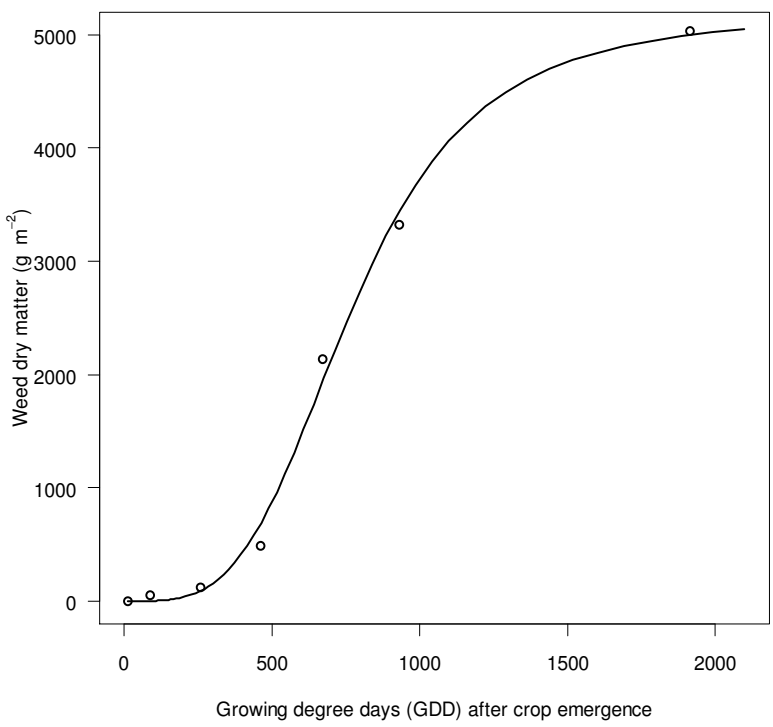

Fig. 2. Weed dry matter $\left(\mathrm{g} \mathrm{m}^{-2}\right)$ response to increasing duration of weed interference, represented by growing degree days (GDD) at Kayseri, Turkey in 2012 and 2013. The regression lines are plotted using Eq. (2), and the parameter values are presented in Table 2

The end of the CPWC also varied between years (Fig. 3). The end of the critical period for weed control was 1014 GDD in 2012 and 958 GDD in 2013 which was similar to 66-63 DAE, at 5\% AYL (Table 4). The end of the critical period for weed control increased as the AYL decreased from $10 \%$ to $2.5 \%$ (Fig. 3). The differences between the beginning and the end of the critical period for weed control in both years were probably the result of the difference in weed densities between the growing seasons (Table 1) and this might be due to the variations in the time of sowing and amount of rainfall received in each respective year (Tursun et al., 2007). 
Table 4. The critical period of weed control (CPWC) for potato at Kayseri, Turkeyin 2012 and2013 expressedingrowing degree days (GDD) and daysaftercropemergence(DAE)

\begin{tabular}{|c|c|c|c|}
\hline \multirow[b]{2}{*}{ Years } & \multirow{2}{*}{$\begin{array}{c}\text { Yield } \\
\text { reduction } \\
(\%)\end{array}$} & \multicolumn{2}{|c|}{ CPWC } \\
\hline & & GDD & DAE \\
\hline \multicolumn{4}{|c|}{ The beginning of the CPWC } \\
\hline \multirow{3}{*}{2012} & 2.5 & 75 & 6 \\
\hline & 5 & 112 & 8 \\
\hline & 10 & 171 & 13 \\
\hline \multirow{3}{*}{2013} & 2.5 & 99 & 7 \\
\hline & 5 & 135 & 10 \\
\hline & 10 & 186 & 15 \\
\hline \multicolumn{4}{|c|}{ The end of the CPWC } \\
\hline \multirow{3}{*}{2012} & 2.5 & 1219 & 76 \\
\hline & 5 & 1014 & 66 \\
\hline & 10 & 838 & 57 \\
\hline \multirow{3}{*}{2013} & 2.5 & 1137 & 72 \\
\hline & 5 & 958 & 63 \\
\hline & 10 & 801 & 55 \\
\hline
\end{tabular}

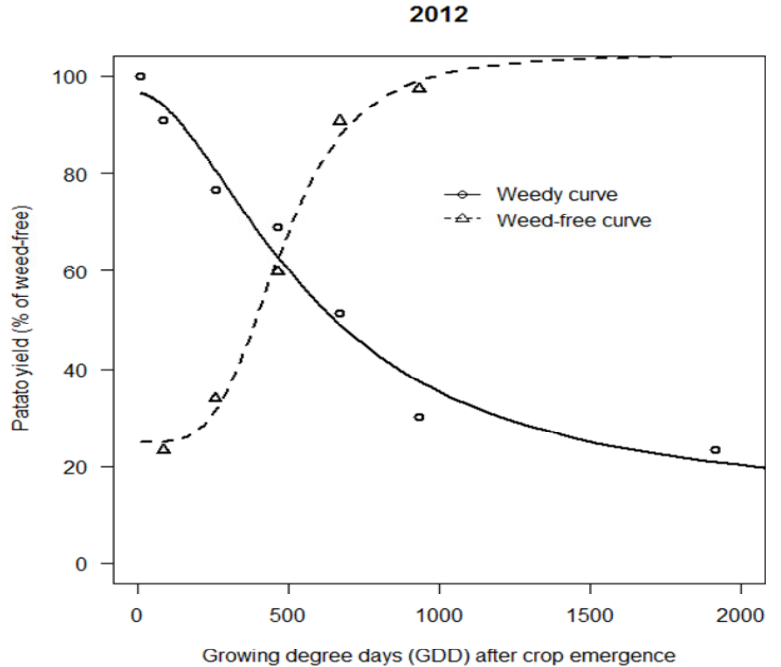

2013

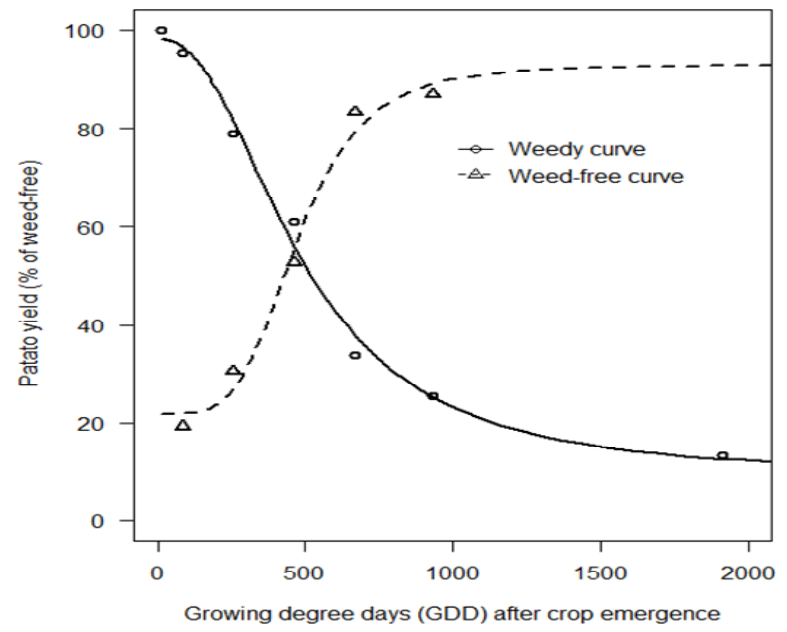

Fig. 3. Effect of weed interference on potato yield (\% of weed-free) as represented by growing degree days (GDD) at Kayseri, Turkey in 2012 and 2013. The regression lines are plotted using Eq. (2), and the parameter values are presented in Table 3
Potato tuber yield was reduced by $73-97 \%$ when weeds were allowed to compete with the crop from planting to harvest. This is consistent with Ahmadvand et al. (2009) who stated that both tubers weight per plant and tuber yield of potato decreased with the increasing duration of weed presence. Uremis et al. (2009) reported that tuber yield lost, compared to season long weedy plots with weedless ones, were between $29 \%$ and $60 \%$. When class-A tubers were in consideration they obtained moderately higher yield lost. These results suggest that the effect of weed competition not only affects the volume of crop production but also crop quality too. Similar results that weeds affect yield and quality of crops were reported by Bukun (2004), in cotton, Isik et al. (2006) in corn and Tursun et al. (2007) in leek.

The results indicated that weed control measures in the Central Anatolian Region of Turkey begin 7-10 days after potato emergence. Previous studies have reported similar results (Rușen, 2006; Ahmadvand et al., 2009). Several studies have shown that the end of CPWC was variable and highly dependent on the density, competitiveness, and emergence periodicity of the weed population (Evans et al., 2003; Bukun 2004).

In Turkey, mechanical weed control such as hoeing and herbicide applications are the principle types of weed control methods in the potato. As a result of early CPWC ( 1 week AE), growers could improve their timing of post emergence herbicide applications and mechanical weed control. Further studies should be carried out in order to determine the CPWC in other locations where weed populations are different from those reported here.

Detail information on CPWC in potato could assist with decision-making on the correct timing for the application of herbicide at the post emergence stage of crops. Enhanced knowledge and usage of the CPWC would also lead to more effective and efficient ways of weed control including farming. It follows that reducing herbicide care by the introduction of more accurate farming programs would almost certainly reduce the risk of environmental pollution and the stress factors involved in trying to assess the most herbicide-resistant weeds (Hall et al., 1992).

\section{Conclusions}

The development of an Integrated Weed Management System (IWM) requires knowledge of the behaviour of weeds in the agro ecosystem, including possible effects on crop yield. The CPWC is an essential part of formulating strategies for IWM. The amount of interference between potato and weeds is affected in part by limiting resources like water, nutrients, and light. Potato yield is therefore directly related and dependent on its ability to secure as much of these resources as possible throughout the growing season. Weeds should have an insignificant effect on potato yield if they are controlled at the correct time. Based on the $5 \%$ acceptable yield loss, results suggest that under the experimental conditions of this study potato tolerates weed interference up until 7 to 10 days after crop emergence (DAE), thus indicating that control measures should begin at that stage. The crop should be kept weed free up until 63 to 66 days after crop emergence (DAE) in order to prevent yield loss in excess of $5 \%$. Weeds that emerge after the 63 to $66 \mathrm{DAE}$ grow in a competitive disadvantage in comparison with potato. 
360

\section{Acknowledgements}

This work was supported by the Scientific Research Projects Department of Erciyes University, grant number FBA-12-3870.

\section{References}

Ahmadvand G, Mondani F, Golzardi F (2009). Effect of crop plant density on critical period of weed competition in potato. Scientia Horticulturae 121:249-254.

Akça A, Isik D (2013). Determination of weed species in sugar beet field (Beta vulgaris L.) in Kayseri Province in Turkey. Proceedings of the 16th EWRS, European Weed Research Society Symposium. Samsun, Turkey,pp 132.

Baziramakenga R, Leroux GD (1994). Critical period of quackgrass (Elytrigia repens) removal in potatoes (Solanum tuberosum). Weed Science $42(4): 528-533$.

Baziramakenga R, Leroux GD (1998). Economic and interference threshold densities of couchgrass (Elytrigia repens) in potato (Solanum tuberosum). Weed Science 46(2):176-180.

Boydston RA, Hutchinson PJS, Bellinder R(2008). Weed management. In: Johnson D (Ed). Potato Health Management. Boydston, MN APS Presspp 223-233.

Bukun B (2004). Critical periods for weed control in cotton in Turkey. Weed Research 44:404412.

Ciuberkis S, Bernotas S, Raudonius S, Felix F (2007). Effect of weed emergence time and intervals of weed and crop competition on potato yield. Weed Technology 21:612-617.

Costa NV, Cardoso LA, Rodrigues ACP, Martins D (2008). Weed interference periods in potato crop. Planta Daninha 26:83-91.

Evans SP, Knezevic SZ, Lindquist JL, Shapiro CA, Blankenship EE (2003). Nitrogen application influences the critical period for weed control in corn. Weed Science 51:408-417.

Felix J, Boydston RA (2010). Evaluation of Imazosulfuron for yellow nutsedge (Cyperus esculentus) and broadleaf weed control in potato. Weed Technology 24:471-477.

Gilmore EC, Rogers RS (1958). Heat units as a method of measuring maturity in corn. Agronomy Journal 50:611-615.

Gitsopoulos TK, Damalas CA, Georgoulas I (2014). Herbicide mixtures for control of water smartweed (Polygonum amphibium) and wild buckwheat (Polygonum convolvulus) in potato. Weed Technology 28:401-407.

Gunel E, Çalışkan ME, Kuşman N, Tuğrul KM, Yulmaz A, Ağırnaslıgil T, Onaran H (2010). Nişasta ve Şeker Bitkileri Üretimi, [Production of starch and sugar crops]. Proceedings of the VII Technic Congress of Turkish Agricultural Engineering, Ankara, Turkey,pp 377-396.

Hall MR, Swanton CJ, Anderson GW (1992). The critical period of weed control in grain corn (Zeamays). Weed Science 40:441-447.

Haverkort A (1981). Potato production in Turkey, and its improvement in the Gudalan Valley. Proceedings of International Potato Center (Region IV) and The Turkish National Potato Research and Training Programme, Menemem, Turkey pp 35.
Iş1k D, Mennan H, Bukun B, Oz A, Ngouajio M (2006).The critical period forweed control in corn in Turkey. Weed Technology 20(4):867-872.

Knezevic SZ, Evans SP, Blankenship EE, Van Acker RC, Lindquist JL (2002). Critical period for weed control: the concept and data analysis. Weed Science 50:773-786.

Knezevic SZ, Streibig JC, Ritz C (2007). Utilizing R software package for dose-response studies: the concept and data analysis. Weed Technology 21:840-848.

KnezevicSZ,Datta A (2015). The critical period for weed control: Revisiting data analysis. Weed Science 63(Sp1):188-202.

Nasrullah JM, Robert BD, Michael KT, Joseph JP (1992). Dry matter accumulation in potato clones under seasonal high temperature conditions in Pakistan. American Journal of Potato Research 69:667676.

R Development Core Team (2006). R: A language and environment for statistical computing, R Foundation for Statistical Computing, Vienna, Austria. http://www.R-project.org.

Ruşen M (2006). Critical periods for weed control in potato (Solanum tuberosum L.).MScDissertation, University of Ataturk

Solan RL, Colquhoun JB, Rittmeyer RA, Heider DJ (2011). Cultivarspecific weed management programs for 'russet burbank' and 'bannock russet' potato production in Wisconsin. HortTechnology 21(4):451460.

Swanton CJ, Weise SF (1991). Integrated weed management: The rationale and approach. Weed Technology 5:657-663.

Tripathi B, Singh CM, Bhargava M (1989). Comparative efficacy of herbicides in potato under conditions of North-Western Himalayas. Pesticides 23:37-38.

TUIK (2015). Statistical yearbook. Food and Agriculture Organization of Turkey. Retrieved 2015 Oct 12 from http://www.tuik.gov.tr.

Turner RJ, Lennartsson ME, Bond W, Grundy AC (1999). Organic weed control-getting it right in time. In: Proceedings of the Brighton Conference-Weeds, Brighton pp 969-974.

Tursun N, Bukun B, Karacan SC, Ngouajio M, Mennan H (2007). Critical period for weed control in leek (Allium porrum L.). HortScience 42:106-109.

Tursun N, Akinci IE, Uludag A, Pamukoglu Z, Gozcu D (2012). Critical period for weed control in direct seeded red pepper (Capsicum annum L.). Weed Biology and Management 12:109-115.

Uremis I, Caliskan ME, Uludag A, Caliskan S (2009). Weed management in early season potato production in the Mediterranean conditions of Turkey. Bulgarian Journal of Agricultural Science 15:423-434.

Zimdahl RL (2004). Weed-crop competition. A Review. 2nd Ed Blackwell PublishingUSA pp220. 